\title{
Designing of Triazine Based Dendrimer and its Application in Removal of Heavy Metal Ions from Water
}

\author{
DHAVAL GAJJAR, RINKESH PATEL, HEMA PATEL and \\ PRAVINKUMAR M. PATEL ${ }^{*}$
}

Department of Industrial Chemistry, V.P. \& R.P.T.P. Science College, Affiliated to Sardar Patel University, Vallabh Vidhyanagar, Gujarat, India

drpravinpatel@rediffmail.com

Received 5 February 2014 / Accepted 20 February 2014

\begin{abstract}
A hydroxyl terminated triazine based dendrimer was synthesized up to generation 3 from $N, N^{\prime}$-biz(4,6-dichloro-1,3,5-triazin-2-yl)propane-1,3-diamine as core using divergent method. Synthesized dendrimer and its generations were characterized by FT-IR, ${ }^{1} \mathrm{H}$ NMR, ${ }^{13} \mathrm{C}$ NMR and elemental analysis. Adsorption behavior of full generation dendrimer G1, G2 and G3 were evaluated for metal ions such as $\mathrm{Cu}, \mathrm{Ni}$ and $\mathrm{Zn}$ from aqueous solutions by ETDA method. Sorption capacities of these generations were evaluated in relation to $\mathrm{pH}$ and generation number. Dendrimer-metal complexes were further characterized by FT-IR and TGA to confirm presence of metal in final metal containing dendrimer.
\end{abstract}

Keywords: Dendrimer, Metal ion adsorption, Thermo gravimetric analysis, FT-IR

\section{Introduction}

Dendrimers are nanosized, void spaced, monodispersed macromolecules blessed with high degree of terminal functionality and branching ${ }^{1-2}$. Because of these unique properties, dendrimers have already displayed their potential in field of drug delivery ${ }^{3}$, cancer therapy ${ }^{4}$, catalysis $^{5}$, dendrimer encapsulated nanoparticles ${ }^{6}$.

Triazine trichloride is one of the most important derivatives ${ }^{7}$ known from a long period time. In nucleophilic substitution of triazine trichloride, three chlorine atoms of triazine trichloride can be substituted in temperature controlled manner ${ }^{8}$. Triazine trichloride also shows good selectivity towards aliphatic amino to hydroxyl moiety in attacking nucleophile. Using triazine trichloride a dendrimer can be synthesized without involving functional group interconversion or protection/ deprotection step. Therefore, triazine trichloride was found to be valuable monomer in many dendrimer synthesis ${ }^{9-12}$.

Most of the heavy metals are either toxic or carcinogenic. Discharge of these metals in water sources possesses a great threat to humans and environment ${ }^{13-14}$. Adsorption is one of the methods used for removal of heavy metal ions from water. It has a benefit that it removes metal ions with relatively low concentrations from water. Common adsorbents used for removal of heavy metal ion are activated carbon ${ }^{15}$, oxide minerals ${ }^{16}$, zeolites ${ }^{17}$, polymer fibers ${ }^{18}$, resins ${ }^{19}$, bio adsorbents ${ }^{20}$ etc. 
Due to void spaced structures with high terminal functionality, dendrimers are perfect adsorbents for removal of heavy metal ions such as copper, zinc, nickel cadmium, mercury $e^{21}{ }^{21}$. Diallo et al., ${ }^{22}$ reported the first dendrimer for removal of $\mathrm{Cu}^{2+}$ from water. Polyamidoamine dendrimers were to bind $\mathrm{Cu}$ (II) ions from water and recovered $\mathrm{Cu}(\mathrm{II})$ ions from water using dendrimer mediated ultrafiltration ${ }^{23-24}$. Recently many groups have described extensive studies on the removal of heavy metal ions from water using dendrimer ${ }^{25-27}$.

In present work, we have synthesized $N, N^{\prime}$-biz(4,6-dichloro-1,3,5-triazin-2-yl)propane1,3-diamine as core for dendrimer synthesis ${ }^{28}$. Dendrimer was then developed up to generation 3 using divergent method ${ }^{29-30}$. The synthesized dendrimer and generations were characterized by FT-IR, ${ }^{1} \mathrm{H}$ NMR, ${ }^{13} \mathrm{C}$ NMR and elemental analysis. The dendrimer generations were used as adsorbents to remove heavy metal ions such as $\mathrm{Cu}^{2+}, \mathrm{Ni}^{2+}$ and $\mathrm{Zn}^{2+}$ from water. Adsorption behavior of the dendrimer generations were estimated by EDTA method $^{19}$ in relation to $\mathrm{pH}$ and generation number. Dendrimer metal complexes were further characterized by FT-IR and Thermogravimetric analysis (TGA) to confirm presence of metal in dendrimer metal complexes.

\section{Experimental}

Cyanuric chloride (Triazine trichloride), propane1,3-diamine, acetone, dichloromethane and methanol were purchased from Sigma-Aldrich (India) Ltd. Nickel nitrate $\left(\mathrm{Ni}\left(\mathrm{NO}_{3}\right)_{2} \cdot 6 \mathrm{H}_{2} \mathrm{O}\right)$, copper nitrate $\left(\mathrm{Cu}\left(\mathrm{NO}_{3}\right)_{2} \cdot 6 \mathrm{H}_{2} \mathrm{O}\right)$, zinc nitrate $\left(\mathrm{Zn}\left(\mathrm{NO}_{3}\right)_{2} \cdot 6 \mathrm{H}_{2} \mathrm{O}\right)$, sodium hydroxide and hydrochloric acid were purchased from Merck (India) Ltd. All the reagents and solvents for the synthesis and analysis were used as received. FTIR studies were carried out in the range of 250-4000 $\mathrm{cm}^{-1}$ using Perkin Elmer-Spectrum RX-FTIR spectrometer instrument through $\mathrm{KBr}$ disc and pellet method or nujol mull method. ${ }^{1} \mathrm{H}$ NMR and ${ }^{13} \mathrm{C}$ NMR spectra were recorded at $400 \mathrm{MHz}$ in Brucker Avance II 400 (Germany) using TMS as internal standard. Thermogravimetric analysis was performed on Perkin Elmer Pyris-1 TGA instrument with heating rate of $10{ }^{\circ} \mathrm{C} / \mathrm{min}$ and in nitrogen atmosphere.

\section{Synthesis of N,N'-biz(4,6-dichloro-1,3,5-triazin-2-yl)propane-1,3-diamine (Core)}

Cyanuric chloride $(0.02 \mathrm{mmol})$ was dissolved in dichloromethane and kept in an ice bath. A solution of propane1,3-diamine $(0.01 \mathrm{mmol})$ containing sodium hydroxide $(0.02 \mathrm{mmol})$ in water was added drop wise in the solution of cyanuric chloride at $0-5{ }^{\circ} \mathrm{C}$ with stirring. The solution was stirred at $0-5{ }^{\circ} \mathrm{C}$ for $2 \mathrm{~h}$. Then the solution was filtered, washed with methanol and acetone and dried under vacuum: A white colored solid was formed.

Yield 83\%; FT-IR(KBr, cm $\left.{ }^{-1}\right) v:$ 3291(NH), 2872, 2780(Aliphatic C-H), 1722, 1625 $(\mathrm{C}=\mathrm{N}$ of triazine $), 841,792(\mathrm{C}-\mathrm{Cl}) ;{ }^{1} \mathrm{H}$ NMR $(400 \mathrm{MHz}, \mathrm{DMSO}-d 6) \delta \mathrm{ppm}: 1.8031-1.8649$ $\left(\mathrm{m}, \quad 2 \mathrm{H}, \quad \mathrm{N}-\mathrm{CH}_{2}-\mathrm{C}_{2}-\mathrm{CH}_{2}-\mathrm{N}\right), \quad 3.4304-3.4660 \quad\left(\mathrm{~m}, \quad 4 \mathrm{H}, \quad \mathrm{N}-\mathrm{CH}_{2}-\mathrm{CH}_{2}-\mathrm{CH}_{2}-\mathrm{N}\right){ }^{13} \mathrm{C}-\mathrm{NMR}$ (75MHz, DMSO-d6) $\delta$ ppm: $28.70\left(\mathrm{~N}-\mathrm{CH}_{2}-\mathrm{CH}_{2}-\mathrm{CH}_{2}-\mathrm{N}\right), 38.18\left(\mathrm{~N}-\underline{\mathrm{CH}}_{2}-\mathrm{CH}_{2}-\mathrm{CH}_{2}-\mathrm{N}\right)$, 166.01, 171.66 (Triazine part);Anal. Calcd. for $\mathrm{C}_{9} \mathrm{H}_{8} \mathrm{Cl}_{4} \mathrm{~N}_{8}$ : C, 29.21; $\mathrm{H}, 2.18 ; \mathrm{N}, 30.28$ found: C, 29.30; H, 2.20; N, 30.30 .

\section{Synthesis of generation 1 dendrimer (G1)}

\section{$N, N^{\prime}$-biz(4,6-dichloro-1,3,5-triazin-2-yl)propane-1,3-diamine}

(0.01 mmol) of $N, N^{\prime}$-biz(4,6-dichloro-1,3,5-triazin-2-yl)propane-1,3-diamine was dissolved in an excess of diethanolamine $(0.04 \mathrm{mmol})$ which was used as both solvent and reactant. The resulting mixture was refluxed for $2 \mathrm{~h}$. After cooling, it was dispersed and washed by acetone repeatedly to give generation 1 dendrimer which was light brown colored. 
Yield 75\%; FT-IR $\left(\mathrm{KBr}, \mathrm{cm}^{-1}\right) v: 3373(\mathrm{O}-\mathrm{H}), 2949,2881($ aliphatic $\mathrm{C}-\mathrm{H}), 1664(\mathrm{C}=\mathrm{N}$ of triazine), $1056(\mathrm{C}-\mathrm{O}) ;{ }^{1} \mathrm{H}$ NMR (400MHz, $\left.\mathrm{D}_{2} \mathrm{O}\right) \delta \mathrm{ppm}: 1.9091-1.9403\left(\mathrm{~m}, 2 \mathrm{H}, \mathrm{N}_{-} \mathrm{CH}_{2}-\mathrm{C}_{2}-\right.$ $\mathrm{CH}_{2}-\mathrm{N}$ ), 3.3211-3.3460 (m, 2H, N-CH $\left.-\mathrm{CH}_{2}-\mathrm{CH}_{2}-\mathrm{N}\right), 3.5980-3.6485$ (m, 16H, N-C $\underline{\mathrm{H}}_{2}-\mathrm{CH}_{2}-$ $\mathrm{OH}), 3.9480-3.9856\left(\mathrm{~m}, 16 \mathrm{H}, \mathrm{N}-\mathrm{CH}_{2}-\mathrm{CH}_{2}-\mathrm{OH}\right) ;{ }^{13} \mathrm{C}-\mathrm{NMR}\left(75 \mathrm{MHz}, \mathrm{D}_{2} \mathrm{O}\right) \delta \mathrm{ppm}: 28.72$

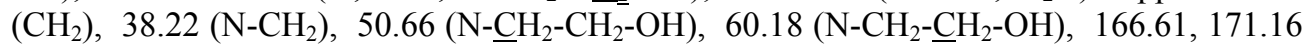
(triazine part);Anal. Calcd.forC ${ }_{25} \mathrm{H}_{48} \mathrm{~N}_{12} \mathrm{O}_{8}: \mathrm{C}, 46.57 ; \mathrm{H}, 7.50 ; \mathrm{N}, 26.07$; Found: C, 46.75; H, $7.55 ; \mathrm{N}, 26.10$.

\section{Synthesis of generation 1.5 dendrimer (G1.5)}

Cyanuric chloride $(0.08 \mathrm{mmol})$ was dissolved in dichloromethane and kept in an ice bath. A solution of $\mathrm{G} 1$ dendrimer $(0.01 \mathrm{mmol})$ containing sodium hydroxide $(0.08 \mathrm{mmol})$ in water was added drop wise in the solution of cyanuric chloride at $0-5{ }^{\circ} \mathrm{C}$ with stirring. The solution was stirred at $0-5{ }^{\circ} \mathrm{C}$ for $2 \mathrm{~h}$ and refluxed for $6 \mathrm{~h}$. Then the solution was filtered, washed with methanol and acetone and dried under vacuum: A white colored solid was formed.

Yield 84\%; FT-IR (KBr, $\left.\mathrm{cm}^{-1}\right)$ v: 3217(N-H), 2833,2780(Aliphatic C-H), 1777, 1752, $1721\left(\mathrm{C}=\mathrm{N}\right.$ of triazine), $1053(\mathrm{C}-\mathrm{O}), 775(\mathrm{C}-\mathrm{Cl}) ;{ }^{1} \mathrm{H}$ NMR $(400 \mathrm{MHz}, \mathrm{DMSO}-d \sigma) \delta \mathrm{ppm}$ : 1.9201-1.9549 (m, 2H, N-CH $\left.2-\mathrm{CH}_{2}-\mathrm{CH}_{2}-\mathrm{N}\right), 3.3425-3.3759$ (m, 4H, $\left.\mathrm{CH}_{2}-\mathrm{NH}\right)$, 4.0759 (m, 16H, N-C $\left.\underline{H}_{2}-\mathrm{CH}_{2}-\mathrm{O}-\mathrm{Tri}\right), 4.1641-4.2015$ (m, 16H, N-CH$\left.{ }_{2}-\underline{\mathrm{CH}}_{2}-\mathrm{O}-\mathrm{Tri}\right){ }^{13} \mathrm{C}-\mathrm{NMR}$ (75MHz, DMSO-d6) $\delta$ ppm: $28.70\left(\mathrm{CH}_{2}\right), 38.10\left(\mathrm{~N}_{-} \mathrm{CH}_{2}\right), \quad 51.01\left(\mathrm{~N}-\mathrm{CH}_{2}-\mathrm{CH}_{2}-\mathrm{O}\right.$-tria),

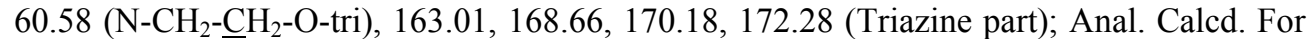
$\mathrm{C}_{49} \mathrm{H}_{40} \mathrm{Cl}_{16} \mathrm{~N}_{36} \mathrm{O}_{8}: \mathrm{C}, 32.19 ; \mathrm{H}, 2.21$; N, 27.58; Found: C, 32.25; H, 2.27; N, 27.60.

\section{Synthesis of generation 2 dendrimer (G2)}

Generation 1.5 dendrimer $(0.01 \mathrm{mmol})$ was dissolved in an excess of diethanolamine $(0.16 \mathrm{mmol})$ which was used as both solvent and reactant. The resulting mixture was refluxed for $2 \mathrm{~h}$. After cooling, it was dispersed and washed by acetone repeatedly to give generation 2 dendrimer which was light brown colored.

Yield 75\%; FT-IR (KBr) v: 3356(O-H), 2942, 2881, 2840 (aliphatic C-H), 1676, $1619(\mathrm{C}=\mathrm{N}$ of triazine $), 1065(\mathrm{C}-\mathrm{O}) ;{ }^{1} \mathrm{H}$ NMR $\left(400 \mathrm{MHz}, \mathrm{D}_{2} \mathrm{O}\right) \delta \mathrm{ppm}: 1.9331-1.9694(\mathrm{~m}, 2 \mathrm{H}$, $\left.\mathrm{N}-\mathrm{CH}_{2}-\underline{\mathrm{C}}_{2}-\mathrm{CH}_{2}-\mathrm{N}\right), 3.3225-3.3519$ (m, 4H, $\left.\underline{\mathrm{H}}_{2}-\mathrm{NH}\right), 3.6813-3.7303$ (m, 64H, N-C $\underline{\mathrm{H}}_{2}-\mathrm{CH}_{2}-$ $\mathrm{OH}), 3.8631-3.9182\left(\mathrm{~m}, 64 \mathrm{H}, \mathrm{N}_{-} \mathrm{CH}_{2}-\mathrm{C}_{2}-\mathrm{OH}\right), 4.0175-4.0759$ (m, $\left.16 \mathrm{H}, \mathrm{N}-\mathrm{C}_{2}-\mathrm{CH}_{2}-\mathrm{O}-\mathrm{tri}\right)$, 4.1641-4.2015 (m, 16H, N-CH ${ }_{2}-\underline{C H}_{2}-\mathrm{O}-$ tri); ${ }^{13} \mathrm{C}-\mathrm{NMR}\left(75 \mathrm{MHz}, \mathrm{D}_{2} \mathrm{O}\right) \delta \mathrm{ppm}: 28.50\left(\mathrm{CH}_{2}\right)$, $38.08\left(\mathrm{~N}-\mathrm{CH}_{2}\right), 60.81\left(\mathrm{~N}-\underline{\mathrm{CH}}_{2}-\mathrm{CH}_{2}-\mathrm{O}-\right.$ tri $), 61.28\left(\mathrm{~N}-\mathrm{CH}_{2}-\mathrm{CH}_{2}-\mathrm{OH}\right), 63.88\left(\mathrm{~N}-\mathrm{CH}_{2}-\mathrm{CH}_{2}-\mathrm{Otri}\right)$, $65.70\left(\mathrm{~N}_{-} \mathrm{CH}_{2}-\mathrm{CH}_{2}-\mathrm{OH}\right), 163.01,168.66,170.78,172.28$ (Triazine portion); Anal. Calcd. For $\mathrm{C}_{113} \mathrm{H}_{200} \mathrm{~N}_{52} \mathrm{O}_{40}$ : C, 46.37; H, 6.89; N, 24.88; Found: C, 46.40; H, 6.95; N, 24.90.

\section{Synthesis of generation 2.5 dendrimer (G2.5)}

Cyanuric chloride $(0.32 \mathrm{mmol})$ was dissolved in dichloromethane and kept in an ice bath. A solution of $\mathrm{G} 2$ dendrimer $(0.01 \mathrm{mmol})$ containing sodium hydroxide $(0.32 \mathrm{mmol})$ in water was added drop wise in the solution of cyanuric chloride at $0-5{ }^{\circ} \mathrm{C}$ with stirring. The solution was stirred at $0-5{ }^{\circ} \mathrm{C}$ for $2 \mathrm{~h}$ and refluxed for $6 \mathrm{~h}$. Then the solution was filtered, washed with methanol and acetone and dried under vacuum: A white colored solid was formed.

Yield: 70\%; FT-IR (KBr, cm ${ }^{-1}$ ) v: 3215(NH), 2881, 2833(aliphatic C-H), 1778, 1752, $1722\left(\mathrm{C}=\mathrm{N}\right.$ of triazine), $1054(\mathrm{C}-\mathrm{O}), 776 \quad(\mathrm{C}-\mathrm{Cl}) ;{ }^{1} \mathrm{H}$ NMR $(400 \mathrm{MHz}$, DMSO-d6) $\delta$ ppm:3.3382-3.3728(t, $\left.4 \mathrm{H}, \mathrm{CH}_{2}-\mathrm{N}\right), 3.9662-4.0226\left(\mathrm{~m}, 80 \mathrm{H}, \mathrm{N}-\mathrm{C}_{2}-\mathrm{CH}_{2}-\mathrm{O}-\mathrm{Tri}\right), 4.0777-$ $4.1440\left(\mathrm{~m}, 80 \mathrm{H}, \mathrm{N}-\mathrm{CH}_{2}-\mathrm{CH}_{2}-\mathrm{O}-\mathrm{Tri}\right) ;{ }^{13} \mathrm{C}-\mathrm{NMR}(75 \mathrm{MHz}, \mathrm{DMSO}-d \sigma) \delta \mathrm{ppm}: 28.8\left(\mathrm{~N}_{-} \mathrm{CH}_{2}-\right.$ $\left.\mathrm{C}_{2}-\mathrm{CH}_{2}-\mathrm{N}\right), 38.2\left(\mathrm{~N}-\mathrm{CH}_{2}-\mathrm{CH}_{2}-\mathrm{CH}_{2}-\mathrm{N}\right), 60.0\left(\mathrm{~N}-\mathrm{CH}_{2}-\mathrm{CH}_{2}-\mathrm{OH}\right), 61.2\left(\mathrm{~N}-\mathrm{CH}_{2}-\mathrm{CH}_{2} \mathrm{O}-\right.$ tri), 
63.3(N-CH$\left.-\mathrm{CH}_{2}-\mathrm{OH}\right), 65.5\left(\mathrm{~N}-\mathrm{CH}_{2}-\mathrm{CH}_{2}-\mathrm{O}-\mathrm{Tri}\right), 164.1,166.4,168.8,171.7,172.5,174.0$ (Triazine Portion); Anal Calcd. forC $\mathrm{C}_{209} \mathrm{H}_{168} \mathrm{Cl}_{64} \mathrm{~N}_{148} \mathrm{O}_{40}$ : C, 32.74; H, 2.19; N, 27.04; Found: C, 32.80; H, 2.25; N, 27.17.

\section{Synthesis of generation 3 dendrimer (G3)}

Generation 2.5 dendrimer $(0.01 \mathrm{mmol})$ was dissolved in an excess of diethanolamine $(0.64 \mathrm{mmol})$ which was used as both solvent and reactant. The resulting mixture was refluxed for $2 \mathrm{~h}$. After cooling, it was dispersed and washed by acetone repeatedly to give generation 1 dendrimer which was light brown colored.

Yield: 71\% FT-IR (KBr, cm $\left.{ }^{-1}\right)$ v: 3371(OH), 2948, 2839(Aliphatic C-H), 1733(C=N of triazine), 1063(C-O); ${ }^{1} \mathrm{H}$ NMR (400MHz, $\left.\mathrm{D}_{2} \mathrm{O}\right) \delta$ ppm: 3.3211-3.3440 (t, $\left.4 \mathrm{H}, \mathrm{CH}_{2}-\mathrm{N}\right)$, $3.6438-3.7243\left(\mathrm{~m}, 264 \mathrm{H}, \mathrm{N}-\mathrm{CH}_{2}-\mathrm{CH}_{2}-\mathrm{OH}\right), 3.7929-3.8586\left(\mathrm{~m}, 264 \mathrm{H}, \mathrm{N}-\mathrm{CH}_{2}-\mathrm{CH}_{2}-\mathrm{OH}\right)$, 3.9107-3.9520 (m, 80H, N-C $\left.\underline{\mathrm{H}}_{2}-\mathrm{CH}_{2}-\mathrm{O}-\mathrm{Tri}\right), \quad 4.0197-4.0315\left(\mathrm{~m}, 80 \mathrm{H}, \mathrm{N}-\mathrm{CH}_{2}-\mathrm{CH}_{2}-\mathrm{O}-\mathrm{Tri}\right)$; ${ }^{13} \mathrm{C}-\mathrm{NMR}\left(75 \mathrm{MHz}, \mathrm{D}_{2} \mathrm{O}\right): 28.00\left(\mathrm{~N}-\mathrm{CH}_{2}-\mathrm{CH}_{2}-\mathrm{CH}_{2}-\mathrm{N}\right), 38.14\left(\mathrm{~N}-\mathrm{CH}_{2}-\mathrm{CH}_{2}-\mathrm{CH}_{2}-\mathrm{N}\right), 59.90(\mathrm{~N}-$ $\left.\mathrm{CH}_{2}-\mathrm{CH}_{2}-\mathrm{OH}\right), 60.62\left(\mathrm{~N}-\mathrm{CH}_{2}-\mathrm{CH}_{2}-\mathrm{O}-\mathrm{Tri}\right), 63.31\left(\mathrm{~N}-\mathrm{CH}_{2}-\mathrm{CH}_{2}-\mathrm{OH}\right), 66.69\left(\mathrm{~N}-\mathrm{CH}_{2}-\mathrm{CH}_{2}-\mathrm{O}-\right.$ tri), 168.16, 169.91, 171.51, 175.57, 177.20, 179.11(Triazine portion); Anal Calcd. For $\mathrm{C}_{465} \mathrm{H}_{808} \mathrm{~N}_{212} \mathrm{O}_{168}:$ C, 46.33; H, 6.70; N, 22.31; Found C, 46.40; H, 6.77; N, 22.40.

\section{Batch adsorption experiments}

Aqueous solution of $3 \mathrm{mmol}$ metal salt $\left[\mathrm{Ni}\left(\mathrm{NO}_{3}\right)_{2} \cdot 6 \mathrm{H}_{2} \mathrm{O}, \mathrm{Cu}\left(\mathrm{NO}_{3}\right)_{2} \cdot 6 \mathrm{H}_{2} \mathrm{O}, \mathrm{Zn}\left(\mathrm{NO}_{3}\right)_{2} \cdot 6 \mathrm{H}_{2} \mathrm{O}\right]$ in $20 \mathrm{~mL}$ water was added to $200 \mathrm{mg}$ of dendrimer(G1, G2 and G3) separately. The solution $\mathrm{pH}$ was set at 7,9 and 10 by using $0.1 \mathrm{~N} \mathrm{NaOH}$. The mixture was shaken in a thermostatic water-bath shaker which operated at $25{ }^{\circ} \mathrm{C}$ for $24 \mathrm{~h}$. The metal-dendrimer complexes were collected by filtration, washed with aqueous solution of the same $\mathrm{pH}$ to remove non-complexed metal ions and dried in vacuum oven. The filtrate and washings were collected to $50 \mathrm{~mL}$ volumetric flask and titrated against ethylenediaminetetracetic acid disodium (EDTA-2Na) salt using Murexide indicator to determine amount of metal adsorbed by dendrimer ${ }^{19}$.

\section{Results and Discussion}

Synthetic route used to synthesize triazine based dendrimer is outlined in Scheme 1. Temperature controlled nucleophilic substitution chlorine atom of triazine trichloride was exploited throughput the synthesis.

$N, N$ '-Bis(4,6-dichloro-1,3,5-triazin-2-yl)propane-1,3-diamine was synthesized in first step as core for dendrimer synthesis as per literature method ${ }^{28}$ with modification. Synthesis was carried out at low temperature to ensure that only one chlorine atom of two moles triazine trichloride was replaced by one mole of propane1,3-diamine. Excess of reactants were removed by washing with acetone and methanol as core compound was insoluble in both of these solvents. Core was then reacted with diethanolamine is second step, which was used as both solvent and reactant ${ }^{29}$ at refluxing temperature to give generation 1 (G1) dendrimer. Generation 1 dendrimer (G1) was dispersed in dichloromethane and decanted to remove excess of diethanolamine. G1 dendrimer was again reacted with cyanuric chloride to give 1.5 generation (G1.5) dendrimer. G1.5 was again reacted with diethanolamine to give generation 2 (G2) dendrimer. The steps were iterated to obtain generation $2.5(\mathrm{G} 2.5)$ and 3 (G3) dendrimer by divergent method. The products were washed and dispersed in solvents to remove excess of reactant from final product. The synthetic route was easy and free from tedious protection/ deprotection or interconversion of functional groups. 

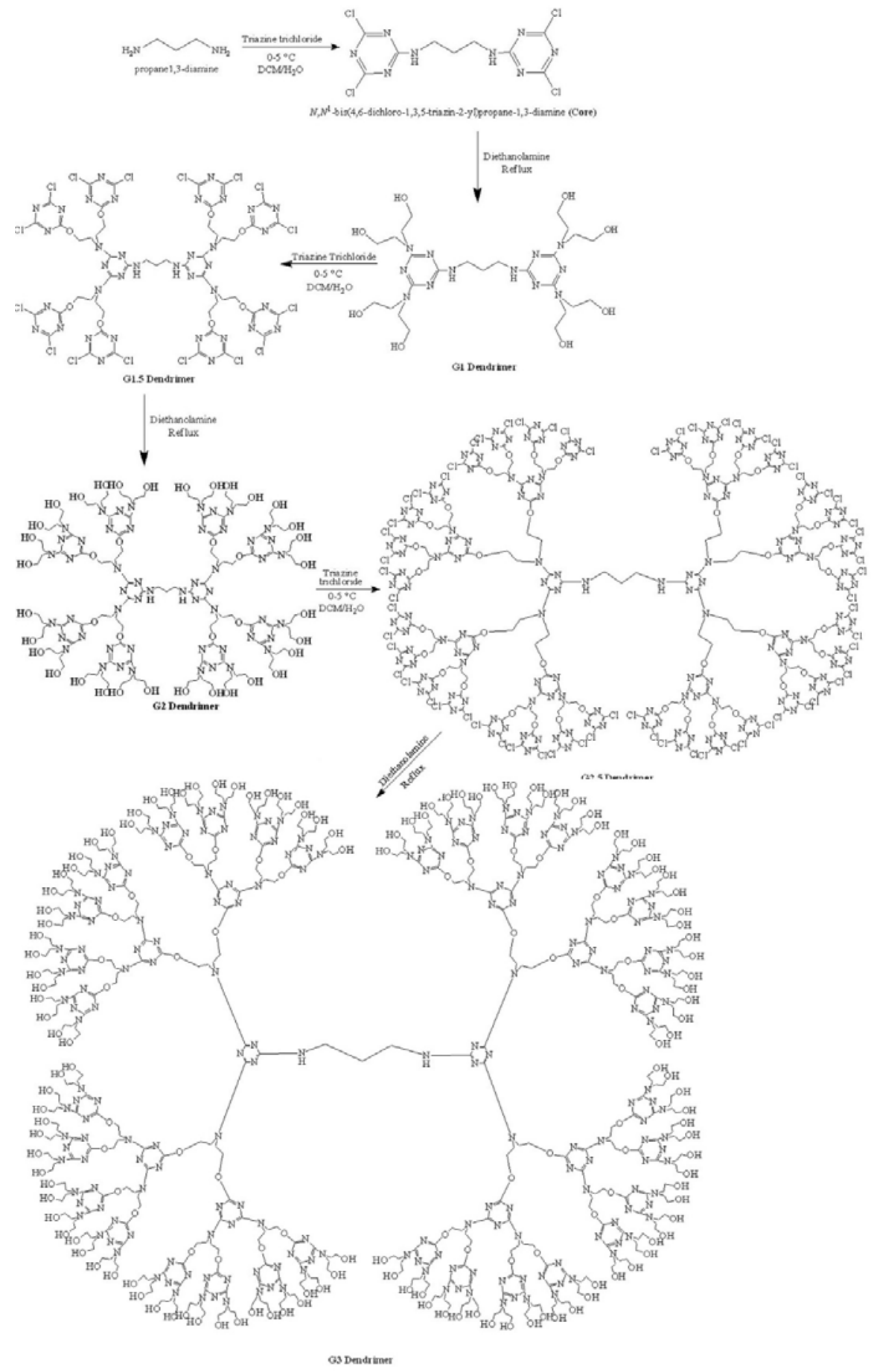

Scheme 1. Synthesis of Triazine based Dendrimer 


\section{Characterization}

Dendrimer generations can be physically confirmed by their solubility and appearance (Table 1). Full generation hydroxyl terminated dendrimers G1, G2 and G3 were freely soluble in water and were light brown liquids. Whereas chlorine terminated core compound and half generation dendrimer G1.5 and G2.5 were insoluble in water and were white solids.

Table 1. Physical description of dendrimer generations

\begin{tabular}{lllll}
\hline Compound & Molecular formula & Appearance & $\begin{array}{c}\text { Solubility } \\
\text { in water }\end{array}$ & $\begin{array}{c}\text { Surface groups } \\
\text { (number) }\end{array}$ \\
\hline Core & $\mathrm{C}_{9} \mathrm{H}_{8} \mathrm{C}_{14} \mathrm{~N}_{8}$ & White solid & Insoluble & $\mathrm{Cl}(4)$ \\
G1 & $\mathrm{C}_{25} \mathrm{H}_{48} \mathrm{~N}_{12} \mathrm{O}_{8}$ & Brown liquid & Soluble & $\mathrm{OH} \mathrm{(8)}$ \\
G1.5 & $\mathrm{C}_{49} \mathrm{H}_{40} \mathrm{Cl}_{16} \mathrm{~N}_{36} \mathrm{O}_{8}$ & White solid & Insoluble & $\mathrm{Cl}(16)$ \\
G 2 & $\mathrm{C}_{113} \mathrm{H}_{200} \mathrm{~N}_{52} \mathrm{O}_{40}$ & Brown liquid & Soluble & $\mathrm{OH}(32)$ \\
G2.5 & $\mathrm{C}_{209} \mathrm{H}_{168} \mathrm{Cl}_{64} \mathrm{~N}_{148} \mathrm{O}_{40}$ & White solid & Insoluble & $\mathrm{Cl}(64)$ \\
G3 & $\mathrm{C}_{465} \mathrm{H}_{808} \mathrm{~N}_{212} \mathrm{O}_{168}$ & Brown liquid & Soluble & $\mathrm{OH} \mathrm{(128)}$ \\
\hline
\end{tabular}

All the dendrimer generations were investigated by FT-IR (Table 2), it was evident that core, half generation dendrimers G1.5 and G2.5 were all chlorine terminated whereas full generation G1, G2 and G3 were all hydroxyl terminated compounds. IR Spectrum of core, G1.5 and G2.5 showed absorption bands at 792, 775 and $776 \mathrm{~cm}^{-1}$ respectively for C-Cl stretching whereas bands for $\mathrm{O}-\mathrm{H}$ stretching was absent which confirmed presence of $\mathrm{C}-\mathrm{Cl}$ groups in their structures an absence of hydroxyl groups. IR spectrum of G1, G2 and G3 showed absorption bands at 3373,3356 and $3371 \mathrm{~cm}^{-1}$ for $\mathrm{O}-\mathrm{H}$ stretching and showed no absorption band for $\mathrm{C}-\mathrm{Cl}$ which confirmed presence of hydroxyl groups in their structures. Both full and half generation dendrimer showed absorption bands for $\mathrm{C}=\mathrm{N}$ stretching between $1700-1680 \mathrm{~cm}^{-1}$ which confirms presence of triazine ring. It was also noted that all dendrimer generations showed C-O stretching frequency for either alchohol linkage in case of full generation dendrimer or ether linkage for half generation dendrimers only exception was core compound. Since core does not contain either alchohol or ether functional group. Progress of reaction and structure of products were investigated by ${ }^{1} \mathrm{H}$ NMR spectroscopy. ${ }^{1} \mathrm{H}$ NMR spectrum of core compound shows two triplets, one at 1.8031-1.8649and second 3.4304-3.4660 which corresponds to propyl moiety in core.

Table 2. IR absorption bands for different generations.

\begin{tabular}{lcccc}
\hline \multirow{2}{*}{ Compound } & \multicolumn{4}{c}{ IR absorption band $\left(\mathrm{cm}^{-1}\right)$ for functional group } \\
\cline { 2 - 5 } & $\mathrm{O}-\mathrm{H}$ & $\mathrm{C}=\mathrm{N}$ & $\mathrm{C}-\mathrm{O}$ & $\mathrm{C}-\mathrm{Cl}$ \\
\hline Core & - & 1722 & - & 792 \\
G1 & 3373 & 1664 & 1056 & - \\
G1.5 & - & 1777 & 1053 & 775 \\
G2 & 3356 & 1676 & 1065 & - \\
G2.5 & - & 1778 & 1054 & 776 \\
G3 & 3371 & 1733 & 1063 & - \\
\hline
\end{tabular}

${ }^{1} \mathrm{H}$ NMR spectrum of G1 dendrimer shows two triplets at 1.9091-1.9403 and 3.32113.3460 value corresponds to propyl group in core and two multiplets 3.5980-3.6485 and 3.9480-3.9856 which corresponds to two methylene protons of diethanolamine which confirms nucleophilic substitution of chlorine atom in core compound by diethanolamine. Similarly, G1.5 dendrimer showed these triplets at 1.9201-1.9549 and 3.3425-3.3759 for propyl moiety in core but, two multiplets for methylene protons of diethanolamine appeared 
down field at 4.0175-4.0759 and 4.1641-4.2015 due to substitution of hydroxyl proton by triazine trichloride changed environment of methylene protons. ${ }^{1} \mathrm{H}$ NMR spectrum of $\mathrm{G} 2$ shows triplets at 1.9331-1.9694 and 3.3237-3.3519 for core moiety and four multiplets, 3.6873-3.7303, 3.8631-3.9182 for two methylene groups of peripheral diethanolamine and 4.0171-4.0719, 4.1641-4.2014 for two methylene protons of inner diethanolamine since four methylene groups were in four different environments. In ${ }^{1} \mathrm{H}$ NMR spectrum of $\mathrm{G} 2.5$ methylene groups of both inner and peripheral diethanolamine moiety appeared as two multiplets at 3.9662-4.0226 and 4.0777-4.1140 because the dendrimer is terminated by triazinetri chloride there fore shifts of these methylene groups were under two different environments. In case of G3 dendrimer, ${ }^{1} \mathrm{H}$ NMR again showed four multiplets for methylene groups at 3.6438-3.724, 3.7929-3.8586 for peripheral diethanolamine moiety, 3.9107-3.9520 and 4.0197-4.0315for inner diethanolamine groups.

All the products were also investigated by ${ }^{13} \mathrm{C}$ NMR spectroscopy. ${ }^{13} \mathrm{C}$ NMR spectrum of core showed peaks at 28.70 and 38.18 for propyl core and166.01, 171.66 for triazine part of structure. ${ }^{13} \mathrm{C}$ NMR of G1 showed peaks at $28.72,38.22$ for core part, peaks at $166.61,171.16$ for triazine part and 50.66, 60.18 for diethanolamine. ${ }^{13} \mathrm{C}$ NMR of $\mathrm{G} 1.5$ shows peaks at 28.7 and 38.18 for propyl core, peaks at 163.01, 168.66 for inner triazine part 170.18, 172.28 outer triazine part and 51.07, 60.58 for diethanolamine part of structure. ${ }^{13} \mathrm{C}$ NMR spectrum of G2, showed peaks at 28.50, 38.08 for core part, 163.01, 168.66 for inner triazine part and 170.18, 172.28 for outer triazine part along with peaks at $61.28,65.70$ for inner methylene groups and $60.81,63.88$ for outer methylene groups of diethanolamine part. As dendrimer grows no of peaks for triazine part increased which was evident from ${ }^{13} \mathrm{C}$ NMR spectrum of $\mathrm{G} 2.5$ which showed speaks at 28.8, 38.2 for core part, 61.2, 65.5 for inner diethanolamine part and 60.063.3 for outer diethanolamine part and 164.1, 166.4, 168.8, 171.7, 172.5, 174.0 for triazine part of G2.5 dendrimer. ${ }^{13} \mathrm{C}$ NMR of G3 dendrimer showed, 28.00, 38.14 for core part, 59.90, 63.31 for outer diethanolamine part, 60.6266 .69 for inner diethanolamine part and 168.16, 169.91, 171.51, 175.57, 177.20, 179.11 for triazine part. Elemental data of products are given in Table 3. All the calculated percentage matches theoretical percentages which confirm their structures.

Table 3. Elemental data of synthesized dendrimers

\begin{tabular}{lcccccc}
\hline Compound & \multicolumn{4}{c}{ Percentage of elements } \\
\cline { 2 - 7 } & \multicolumn{3}{c}{ Theoretical } & \multicolumn{3}{c}{ Practical } \\
\cline { 2 - 7 } & $\mathrm{C}$ & $\mathrm{H}$ & $\mathrm{N}$ & $\mathrm{C}$ & $\mathrm{H}$ & $\mathrm{N}$ \\
\hline Core & 29.21 & 2.18 & 30.28 & 29.30 & 2.20 & 30.30 \\
G1 & 46.57 & 7.50 & 26.07 & 46.75 & 7.55 & 26.10 \\
G1.5 & 32.19 & 2.21 & 27.58 & 32.25 & 2.27 & 27.60 \\
G 2 & 46.37 & 6.89 & 24.88 & 46.40 & 6.95 & 24.90 \\
G2.5 & 32.74 & 2.19 & 27.04 & 32.80 & 2.25 & 27.17 \\
G3 & 46.33 & 6.70 & 22.31 & 46.40 & 6.77 & 22.40 \\
\hline
\end{tabular}

\section{Metal ion adsorption}

All the hydroxyl terminated full generation dendrimer G1, G2 and G3 were used to adsorb heavy metal ions. Capacities of dendrimers to adsorb $\mathrm{Cu}^{2+}, \mathrm{Ni}^{2+}$ and $\mathrm{Zn}^{2+}$ ions in relation $\mathrm{pH}$ and generation by EDTA method.

The sorption capacities of dendrimer generation in relation to $\mathrm{pH}$ illustrated in Table 4 . For all the dendrimer generations, metal ion adsorption increased with increase in $\mathrm{pH}$. At higher $\mathrm{pH}$ values protonation of ligands decreases which leads to higher metal adsorption ${ }^{26}$. For all metals adsorption was maximum at $10 \mathrm{pH}$. 
Table 4. Sorption capacities of dendrimer generation in relation to $\mathrm{pH}$

\begin{tabular}{ccccc}
\hline \multirow{2}{*}{ Dendrimer } & \multirow{2}{*}{ Metal ion } & \multicolumn{3}{c}{ Metal ion uptake, $\mathrm{mmol} / \mathrm{g}$} \\
\cline { 3 - 5 } & & $\mathrm{pH}=7$ & $\mathrm{pH}=9$ & $\mathrm{pH}=10$ \\
\hline \multirow{6}{*}{$\mathrm{G} 1(\mathrm{OH})_{8}$} & $\mathrm{Cu}^{2+}$ & 1.20 & 2.10 & 2.30 \\
& $\mathrm{Ni}^{2+}$ & 1.07 & 1.97 & 2.10 \\
& $\mathrm{Zn}^{2+}$ & 0.95 & 1.91 & 2.06 \\
$\mathrm{G} 2(\mathrm{OH})_{32}$ & $\mathrm{Cu}^{2+}$ & 2.10 & 3.55 & 3.61 \\
& $\mathrm{Ni}^{2+}$ & 2.04 & 3.43 & 3.46 \\
& $\mathrm{Zn}^{2+}$ & 2.04 & 3.30 & 3.34 \\
& $\mathrm{Cu}^{2+}$ & 4.08 & 5.03 & 5.20 \\
$\mathrm{G} 3(\mathrm{OH})_{128}$ & $\mathrm{Ni}^{2+}$ & 3.90 & 4.44 & 4.97 \\
& $\mathrm{Zn}^{2+}$ & 3.83 & 4.35 & 4.71 \\
\hline
\end{tabular}

Table 5 shows sorption capacities of dendrimer generation at $\mathrm{pH} 10$. It was revealed that sorption capacities of the dendrimer generation increases with increase in generation number. Generation 3 dendrimer had highest sorption capacity. As generation number increased, no of terminal hydroxyl groups also increased which led to more closed structure and high metal ion adsorption. It was also revealed that dendrimers showed highest adsorption for $\mathrm{Cu}^{2+}$ ions and lowest adsorption for $\mathrm{Zn}^{2+}$ ions.

Table 5. Sorption capacities of dendrimer generation at $\mathrm{pH} 10$

\begin{tabular}{clll}
\hline \multirow{2}{*}{ Dendrimer } & \multicolumn{3}{c}{ Metal ions adsorbed $\mathrm{mmol} / \mathrm{g}$} \\
\cline { 2 - 4 } & $\mathrm{Cu}^{2+}$ & $\mathrm{Ni}^{2+}$ & $\mathrm{Zn}^{2+}$ \\
\hline $\mathrm{G} 1$ & 2.30 & 2.10 & 2.06 \\
$\mathrm{G} 2$ & 3.61 & 3.46 & 3.33 \\
$\mathrm{G} 3$ & 5.20 & 4.97 & 4.71 \\
\hline
\end{tabular}

\section{Characterization of dendrimer metal complexes}

G3 dendrimer showed highest metal ion adsorption capacity. G3 dendrimer containing $\mathrm{Cu}$, $\mathrm{Ni}$ and $\mathrm{Zn}$ was further characterized by FT-IR and Thermo gravimetric analysis and compared with pure G3 dendrimer to confirm presence of these metals in final metal containing dendrimer.

FTIR results are furnished in Table 6. FT-IR spectrum of metal containing dendrimer were compared with FT-IR spectrum of parent pure dendrimers which gives information about binding site in G3 dendrimer. IR absorption band at $3371 \mathrm{~cm}^{-1}$ resembles to hydroxyl group in pure generation 3 dendrimer. This absorption band shifts to $3411 \mathrm{~cm}^{-1}, 3484 \mathrm{~cm}^{-1}$ and $3441 \mathrm{~cm}^{-1}$ after adsorption of $\mathrm{Cu}, \mathrm{Ni}$ and $\mathrm{Zn}$ respectively. A very little shift is observed for $\mathrm{C}-\mathrm{O}$ at $1064 \mathrm{~cm}^{-1}$ and $\mathrm{C}-\mathrm{H}$ at $2848 \mathrm{~cm}^{-1}$ from the parent $\mathrm{G} 3$ dendrimer. So it was revealed that surface hydroxyl group may be the active binding site for metal ions adsorption $^{26}$.

Table 6. FT-IR absorption bands for dendrimer and metal containing dendrimer

\begin{tabular}{cccc}
\hline Pure dendrimer & \multicolumn{3}{c}{ FTIR absorption bands cm } \\
\cline { 2 - 4 } and metal containing dendrimer & $\mathrm{O}-\mathrm{H}$ & $\mathrm{C}-\mathrm{H}$ & $\mathrm{C}-\mathrm{O}$ \\
\hline $\mathrm{G} 3$ & 3371 & 2848 & 1063 \\
$\mathrm{G} 3-\mathrm{Cu}$ & 3411 & 2848 & 1063 \\
$\mathrm{G} 3-\mathrm{Ni}$ & 3484 & 2848 & 1063 \\
$\mathrm{G} 3-\mathrm{Zn}$ & 3441 & 2848 & 1063 \\
\hline
\end{tabular}


The thermal degradation analyses of the prepared pure and metal containing dendrimer were performed by TGA instrument with heating rate of $10^{\circ} \mathrm{C} \min ^{-1}$ in an $\mathrm{N}_{2}$ atmosphere. TGA (Figure 1) of pure G3 dendrimer shows two stage thermal decomposition, dendrimer losses $18 \%$ of wt. up to $150{ }^{\circ} \mathrm{C}$ due to bound moisture, then decomposes completely up to $600{ }^{\circ} \mathrm{C}$ leaving final residual weight of $7 \%$. Dendrimer metal complexes G3-Cu, G3-Ni and $\mathrm{G} 3-\mathrm{Zn}$ showed same thermal decomposition but final residual weightsat $600{ }^{\circ} \mathrm{C}$ were $15.43 \%, 14.17 \%$ and $12.77 \%$ respectively for due to presence of metal oxides. These confirms presence of metal ions in final dendrimer metal complexes ${ }^{26}$.
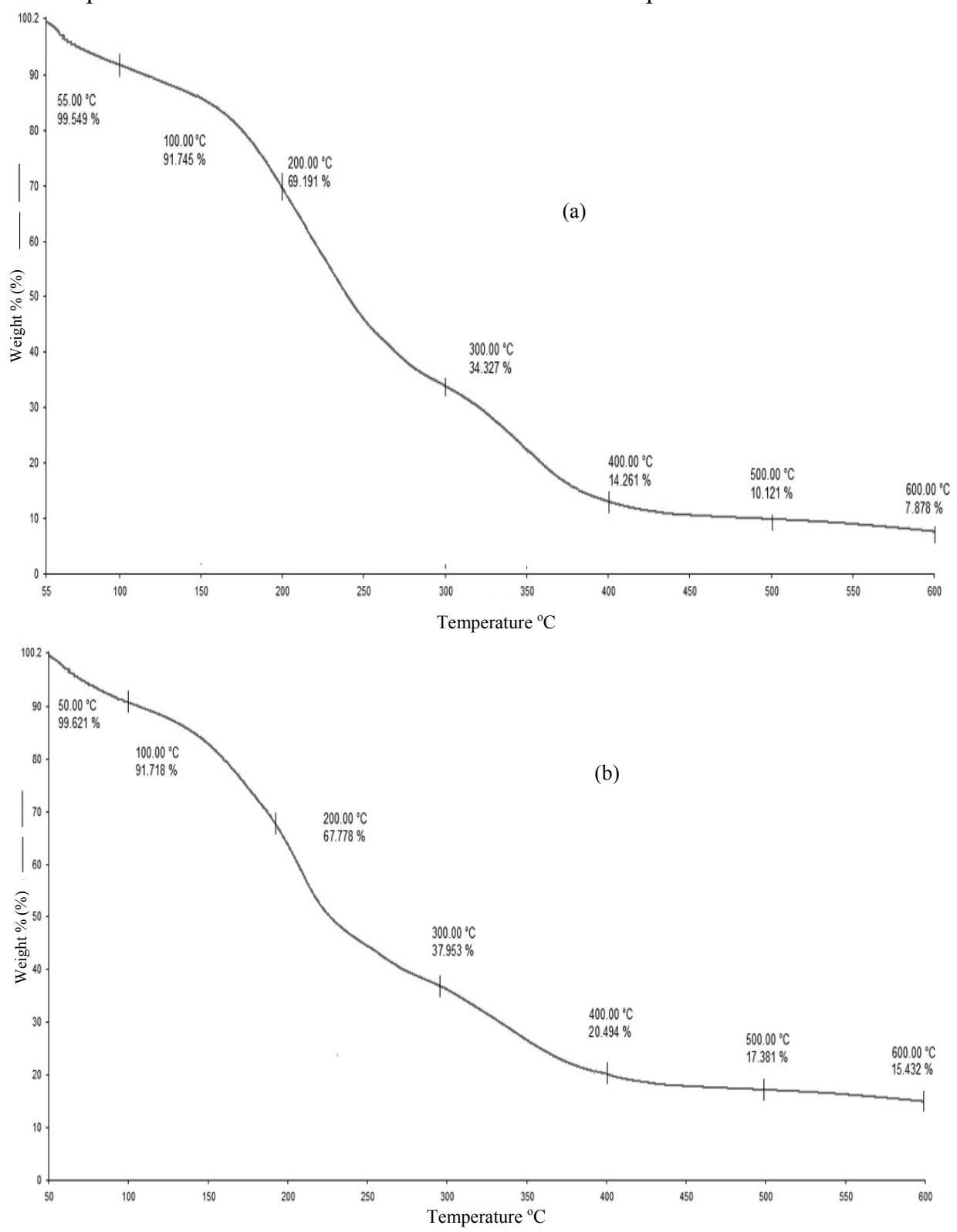

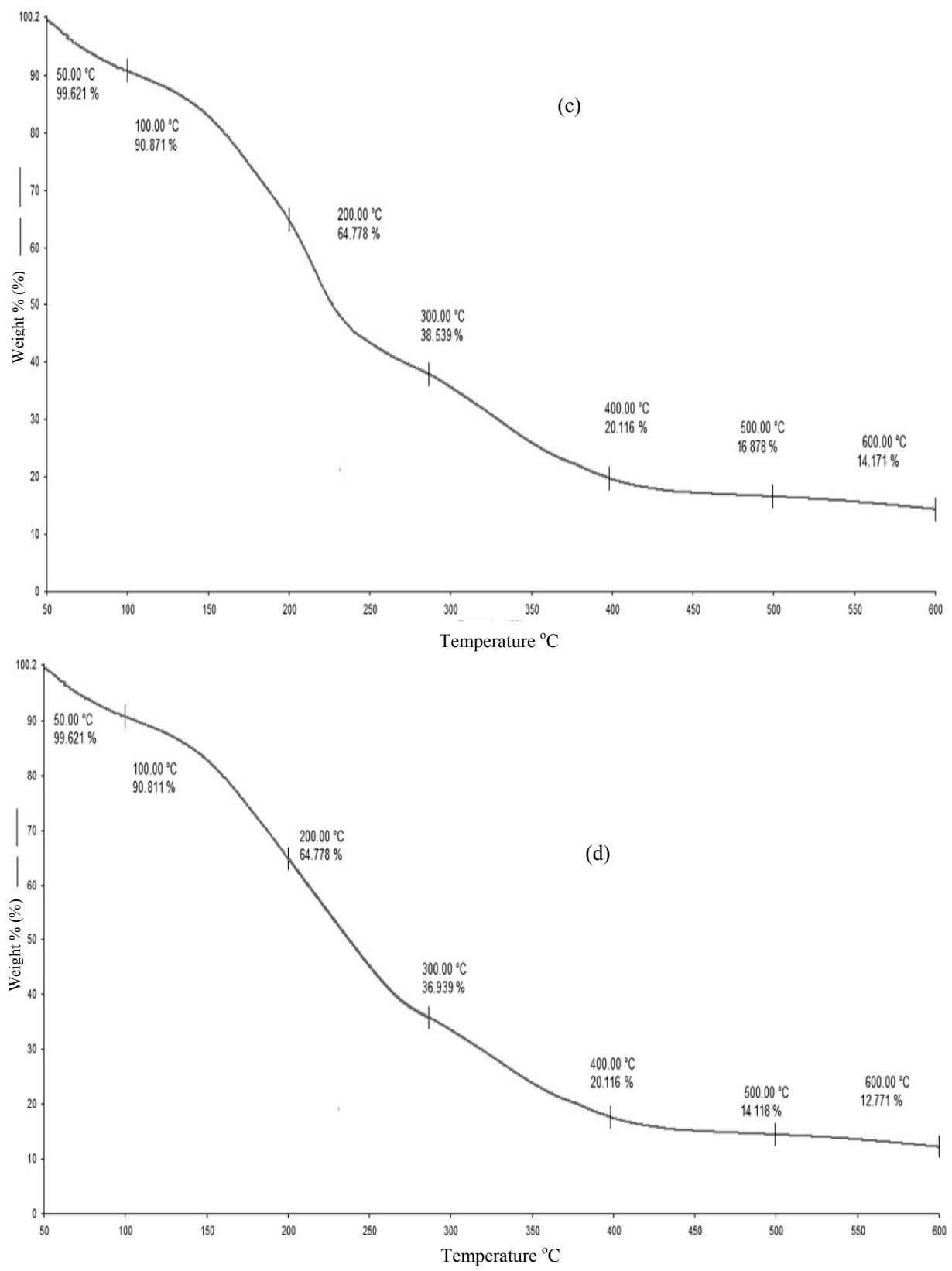

Figure 1. TGA Graphs of a) G3-Dendrimer; b) G3-dendrimer containing $\mathrm{Cu}$ metal; c) G3 dendrimer containing Ni metal; d) G3 dendrimer containing Zn metal

\section{Conclusion}

Hydroxyl terminated triazine based dendrimer was synthesized up to generation 3 using divergent method without involving protection/deprotecion or interconversion of functional group. All the dendrimer generations were fully characterized by spectral techniques. 
Sorption capacities of dendrimer generations increase with increase in generation number and $\mathrm{pH}$. All dendrimer generations showed maximum metal adsorption at $\mathrm{pH} 10$. G3 dendrimer showed highest sorption capacity for all metal ions. FT-IR spectrum and TGA analysis of G3 dendrimer and its metal complexes further confirmed presence of metals in final metal containing dendrimer.

\section{Acknowledgment}

The authors are grateful to The Principal, V.P. \& R.P.T. P. Science College for providing laboratory facility. Authors are also grateful to U.G.C., New Delhi for funding this research work. The authors acknowledge Sophisticated Analytical Instrumentation Facility (SAIF), Punjab University, Chandigarh, Sophisticated Instrumentation Centre for Advanced Research and Testing (SICART), Sardar Patel University Vallabh Vidhyanagar and Central Salt and Marine Chemicals Research Institute (CSMCRI) providing instrumentation facilities.

\section{References}

1. Tomalia D A, Al Acta., 2004, 37(2), 39-57.

2. Patel H N and Patel P M, Int J Pharm Bio Sci., 2013, 4(2), 454-463.

3. Mignani S, Al Kazzouli S E, Bousmina M and Majoral J P, Adv Drug Deliv Rev., 2013, 65(10), 1316-1330; DOI:10.1016/j.addr.2013.01.001

4. Mollazade M, Nejati-Koshki K, Akbarzadeh A, Zarghami N, Nasiri M, JahanbanEsfahlan R and Alibakhshi A, Asian Pac J Cancer Prev., 2013, 14(11), 6925-6928

5. Wang D and Astruc D, Coord Chem Rev., 2013, 257(15-16), 2317-2334; DOI:10.1016/j.ccr.2013.03.032

6. Iyyamperumal R, Zhang L, Henkelman G and Crooks R M, J Am Chem Soc., 2013, 135(15), 5521-5524; DOI:10.1021/ja4010305

7. Miyashita K and Pauling L, J Org Chem., 1976, 41(11), 2032-2034; DOI:10.1021/jo00873a034

8. Zhang W, Jiang J, Qin C, Thomson L M, Parrish A R, Safe S H and Simanek E E, Supramol Chem., 2003, 15(7-8), 607-616; DOI:10.1080/10610270310001605197

9. Kraus G A and Louw S V, J Org Chem., 1998, 63(21), 7520-7521; DOI:10.1080/10.1021/jo980244q

10. Zhang W and Simanek E E, Org Lett., 2000, 2(6), 843-845; DOI:10.1021/o1005585g

11. Song Y C, Young K Y, Marsh A, Carlisle S J and Smith S C, Tetrahedron Lett., 2001, 42(3), 493-496; DOI:10.1016/S0040-4039(00)01999-7

12. Takagi K, Hattori T, Kunisada H and Yuki Y, J PolymSci Part A: Polym Chem., 2000, 38(24), 4385-4395;

DOI:10.1002/1099-0518(20001215)38:24<4385::AID-POLA70>3.0.CO;2-Y

13. Dimitrova S V, Water Res., 2002, 36(16), 4001-4008;

DOI:10.1016/S0043-1354(02)00120-3

14. Babel S and Kurniawan T A, Chemosphere, 2004, 54(7), 951-967; DOI:10.1016/j.chemosphere.2003.10.001

15. Kumar P, Rao R, Chand S, Kumar S, Wasewar K L and Yoo C K, Desalin Water Treat., 2013, 51(13-15), 2529-2536; DOI:10.1080/19443994.2012.749009

16. Ahmed M A, Ali S M, El-Dek S I and Galal A, Mater Sci Eng B, 2013, 178(10), 744-751; DOI:10.1016/j.mseb.2013.03.011

17. Pathaniaa D, Singha P and Siddiqib Z M, Ion Exch Lett., 2013, 6(1-3), 1-4.

18. Monier M and Abdel-latif D A, J Hazard Mater., 2013, 250-251, 122-130; DOI:10.1016/j.jhazmat.2013.01.056 
19. Patel R T, Patel R M, Sinha M T J and Patel P M, Int J Polym Mater Polym Biomet., 2000, 47(2-3), 139-147; DOI:10.1080/00914030008035057

20. Shi J, Luo H, Xiao D, Hu J, Zhang G, Li Y, Lin B, Liang X and Tu Y, J Appl Polym Sci., 2014, 131(2), 39780; DOI:10.1002/app.39780

21. Newkome G R, Moorefield C N and Vogtle F, Dendritic Macromolecules: Concepts, Syntheses, Perspectives. Wiley-VCH: Weinheim, Germany, 2001.

22. Diallo M S, Balogh L, Shafagati A, James Jr H J, Goddard III W A and Tomalia D A, Environ Sci Technol., 1999, 33(5), 820-824; DOI:10.1021/es980521a

23. Diallo M S, Christie S, Swaminathan P, Balogh L, Shi X, Um W, Papelis C, Goddard III W A and Johnson Jr J H, Langmuir, 2004, 20(7), 2640-2651; DOI:10.1021/la036108k

24. Diallo M S, Christie S, Swaminathan P and Johnson Jr.JH and Goddard III W A, Environ Sci Technol., 2005, 39(5), 1366-1377; DOI:10.1021/es048961r

25. Barakat M A, Ramadan M H, Alghamdi M A, Algarny S S, Woodcock H L and Kuhn J N, J Environ Manage., 2013, 117, 50-57; DOI:10.1016/j.jenvman.2012.12.025

26. Golikand A N, Didehban K and Irannejad L, J App Polym Sci., 2012, 123(2), 1245 1251; DOI:10.1002/app.33893

27. Shahbazi A, Younesi H and Badiei A, Chem Eng J., 2011, 168(2), 505-518; DOI:10.1016/j.cej.2010.11.053

28. Lin $\mathrm{X}$, Zhou $\mathrm{J}$ and $\mathrm{Xu}$ D, Chin $J$ Chem., 2012, 30(7), 1485-1489; DOI:10.1002/cjoc.201100557

29. Namazi $\mathrm{H}$ and Adeli M, Polym., 2005, 46(24), 10788-10799; DOI:10.1016/j.polymer.2005.09.020

30. Didehban K, Namazi H and Entezami A A, Iran Polym J., 2009, 18(9), 731-741. 